\title{
Detection of bluetongue virus antibodies in sheep from Paraná, Brazil
}

\section{Deteç̧ão de anticorpos para o vírus da língua azul em ovinos do estado do Paraná, Brasil}

\author{
Maria Carolina Ricciardi Sbizera ${ }^{1}$; Luiz Fernando Coelho da Cunha Filho ${ }^{2 *}$; \\ Michele Lunardi³; Simone Fernanda Nedel Pertile ${ }^{2}$; Thais Helena Constantino \\ Patellii $^{4}$ José Victor Pronievicz Barreto ${ }^{1}$; Edviges Maristela Pituco ${ }^{5}$
}

\section{Highlights:}

Bluetongue, an infectious and non-contagious disease, is prevalent in sheep of Paraná. .

Based on our findings, cELISA is more sensitive and superior than AGID.

Climate plays an important role in occurrence and spread of the disease.

\begin{abstract}
Bluetongue (BT) is an infectious and non-contagious disease caused by bluetongue virus (BTV) belonging to the genus Orbivirus. It is transmitted by a hematophagous vector, Culicoides sp., to ruminants, particularly to sheep, which are most susceptible to this disease. The main serological tests are agar gel immunodiffusion (AGID), which is recommended by the World Organization for Animal Health (OIE), and the competitive enzyme-linked immunosorbent assay (cELISA), which has the advantage of no cross-reaction with other orbiviruses. The aim was to compare the results of these two tests by conducting them on sera collected from sheep in the state of Paraná, Brazil. From March to October 2017, serum samples were collected from 270 sheep from 10 farms in six mesoregions of Paraná. The samples were subjected to AGID and cELISA to detect antibodies against BTV. Based on the test results, we classified the sheep as low, moderate, and high occurrence. The results demonstrated that $64.81 \%(175 / 270)$ of the sheep were seropositive through the cELISA test, showing a high occurrence, and $41.11 \%(111 / 270)$ were seropositive through the AGID test, indicating a moderate occurrence. The concordance between the tests was moderate $(0.51)$ as determined by the Kappa coefficient. Among the studied farms, 90\% (9/10) presented at least one seropositive sheep, and the number of animals tested positive by the cELISA test was higher than those by the AGID test. Favorable climate, which favors the presence and multiplication of the culicoid vector and the occurrence of infection, was the biggest predominant factor responsible for the obtained results. The low occurrence in farms with milder climate suggest that the presence of antibodies also occurs due to the low pathogenicity of circulating serotypes in the different mesoregions studied. It is concluded that BTV infection is present in the sheep herds in Paraná, and the occurrence was moderate detected by AGID test and high detected by cELISA test.
\end{abstract}

Key words: Culicoides. Diagnosis. Occurrence. Orbivirus. Small ruminants.

1 Discentes do Curso de Mestrado do Programa de Pós-Graduação em Saúde e Produção Animal, Universidade Pitágoras Unopar, UNOPAR, Arapongas, PR, Brasil. E-mail: mcrsbizera@gmail.com; jose.proni@hotmail.com

2 Profs. Drs., Programa de Pós-Graduação em Saúde e Produção Animal, UNOPAR, Arapongas, PR, Brasil. E-mail: vtluiz.cunha@, gmail.com; s.pertile@zootecnista.com.br

3 Prof ${ }^{\mathrm{a}} \mathrm{Dr}^{\mathrm{a}}$, Universidade de Cuiabá, UNIC, Cuiabá, MT, Brasil. E-mail: michelelunardi@gmail.com

4 Prof $^{\text {a }}$ Dr $^{\mathrm{a}}$, Universidade Estadual do Norte do Paraná, UENP, Bandeirantes, PR, Brasil. E-mail: thaispatelli@uenp.edu.br

5 Pesquisadora, Dra ${ }^{\text {a }}$ Laboratório de Viroses de Bovídeos, Instituto Biológico de São Paulo, IB, São Paulo, SP, Brasil. E-mail: empituco@gmail.com

* Author for correspondence 


\section{Resumo}

A língua azul (LA) é uma enfermidade infecciosa e não contagiosa causada por um vírus (VLA) do gênero Orbivirus, transmitida por vetores hematófagos Culicoides sp., aos ruminantes sobretudo aos ovinos, espécie mais susceptível. Os principais testes sorológicos utilizados são a Imunodifusão em Gél de Ágar (IDGA), preconizada pela OIE, e o teste Imunoensaio Enzimático Competitivo (ELISAc), sendo que este tem como vantagem não ocorrer reação cruzada contra outros orbivírus. O objetivo do trabalho foi detectar a presença de anticorpos contra o VLA em ovinos no estado do Paraná através dos testes diagnósticos IDGA e ELISAc. Durante os meses de março a outubro de 2017, colheuse sangue de 270 ovinos, em 10 propriedades localizadas em seis mesorregiões paranaenses. As amostras foram submetidas aos testes de IDGA e ELISAc para deteç̧ão de anticorpos contra o VLA. Baseado nos resultados classificaram-se os rebanhos como baixa, moderada ou elevada ocorrência. Os resultados demonstraram elevada ocorrência através do teste de ELISAc, que apresentou $64,81 \%$ (175/270) de ovinos positivos, e moderada ocorrência através do IDGA, com 41,11\% (111/270) de ovinos soropositivos. A concordância obtida entre os testes foi moderada $(0,51)$ através do coeficiente Kappa. O número de ovinos reagentes no exame de ELISAc foi maior que o teste de IDGA em todas as propriedades positivas, demonstrando ser superior. O clima propício foi um dos fatores favoráveis para as ocorrências observadas, pois favorece a presença e multiplicação do vetor Culicoide e a ocorrência da infecção. A baixa ocorrência nas propriedades com clima mais ameno sugere que a presença de anticorpos provavelmente ocorra também pela baixa patogenicidade dos sorotipos circulantes nas diferentes mesorregiões estudadas. Conclui-se que há infecção de VLA no rebanho ovino paranaense, e a detecção de anticorpos para o VLA foi moderada, através do teste de IDGA, e elevada, através do teste ELISAc.

Palavras-chave: Culicoides. Diagnóstico. Ocorrência. Orbivirus. Pequenos ruminantes.

\section{Introduction}

The bluetongue (BT) disease is an infectious, noncontagious disease, which should be mandatorily reported to the authorities (World Organisation for Animal Health [OIE], 2018). It is caused by Orbivirus bluetongue virus (BTV), which belongs to the Reoviridae family. Its 27 serotypes have been characterized worldwide (Roy, 2008; Jenckel et al., 2015).

This virus is transmitted by hematophagous vectors, particularly by midges of Culicoides sp. Domestic and wild ruminants are generally infected. Sheep are the most susceptible species (Dorneles et al., 2012). Factors, such as nutritional and immune status, stress, temperature (Maclachlan, 2004), age and race (Lobato, Guedes, \& Matos, 2015), and the pathogenicity of the serotype (Purse, Carpenter, Venter, Bellis, \& Mullens, 2015), influence the severity of infection.
The disease is distributed worldwide, coinciding with the presence of vectors. It is prevalent approximately between $50^{\circ} \mathrm{N}$ and $35^{\circ} \mathrm{S}$ latitudes, which includes climatic, tropical and subtropical, and temperate regions of the globe (Coetzee, Stokstad, Venter, Myrmel, \& Van Vururen, 2012). High or moderately high temperatures predominate in most of these regions. In addition, vector development and proliferation is favorable in these regions (Dorneles et al., 2012). In Brazil, several studies have shown nationwide prevalence of bluetongue in different domestic and wild ruminant species (Costa, Lobato, Herrmann, Leite, \& Haddad, 2006; Alves et al., 2009; Nogueira, Pituco, Stefano, Curci, \& Cardoso, 2009; Tomich et al., 2009; Souza, Costa, Martinez, Costa, \& Pinheiro, 2010; Mota et al., 2011; Dorneles et al., 2012; Pinheiro et al., 2013; Sbizera et al., 2017; Batista et al., 2018; Silva et al., 2018; Morikawa et al., 2018). 
In Brazil, two outbreaks of this disease occurred in the state of Paraná in 2001 and 2002 (Clavijo et al., 2002; Lager, 2004); however, there is no data on the prevalence available in this state.

BTV infection in sheep is usually associated with clinical signs such as fever, nasal discharge, sialorrhea, oral injury, face and tongue edema, depression, anorexia, and muscle weakness (Gang-Ma et al., 2017). In addition, reproductive disorders such as abortion, stillbirth, and progeny malformations have been observed (Pinheiro et al., 2013). The economic impact associated with this disease stems not only from direct losses in the affected herds but also from restrictions on trade of animals and their products (Dorneles et al., 2012).

The main laboratorial methods for the diagnosis of Blue Tongue recommended by the World Organization for Animal Health (OIE) are based on isolation and identification of the agent, and on serological tests for certification of animals for international transit purposes, where the most used ones are the Agar Gel Immunodiffusion (AGID) and the Competitive Enzyme Immunoassay (cELISA) (Souza et al., 2010).

The AGID test has been one of the standard tests recommended by OIE for the certification of ruminant animals for international transit purposes since 1982; it is economical and simple to perform. However, its disadvantage is the possibility of cross-reaction with other viruses belonging to the genus Orbivirus (OIE, 2018); for example, the virus causing epizootic hemorrhagic cervical disease may show cross reaction in this test (Souza et al., 2010). Unfortunately, the AGID test is capable of determining only seropositive or seronegative animals, and it does not identify the serotypes present in a given seroreactive sample (Costa et al., 2006).

The cELISA test was developed to detect antibodies against the VP7 protein, which is present in the inner layer of the viral particle and contains the major group-specific antigenic determinants (OIE, 2018). Thus, the cELISA test does not show cross-reaction against other orbiviruses (OIE, 2018), and it is recommended mainly to confirm positive results of the AGID test. Because of its sensitivity (Shringi \& Shringi, 2005; Velic, Velic, Bajrovic, Dukic, \& Cano, 2004), cELISA has been recommended as an official OIE test for serological monitoring of antibodies against BTV in small ruminants (Shringi \& Shringi, 2005). Nonetheless, AGID is still the main serological test used for screening animals during transit because it is easy to perform. As no seroepidemiological study of BT has been conducted in the state of Paraná, we aimed to detect the presence of antibodies against BTV in sheep in Paraná using AGID and cELISA.

\section{Materials and Methods}

The study was conducted between March and October 2017. Initially, sheep blood was collected from 10 randomly selected farms, which had already been monitored in 2014 using AGID. Based on the data from 2014, the farms were classified as follows: low occurrence $(0 \%-9.99 \%$ positive sheep; $\mathrm{n}=2)$, moderate occurrence $(10 \%-49.99 \%$ positive sheep; $\mathrm{n}=4)$, and high occurrence $(50 \%-100 \%$ positive sheep; $n=4)$. We classified the farms in this manner because there is no specification in the literature regarding the classification of sheep farms based on the occurrence of BTV infection in Brazil.

Overall, this study covered farms located in the municipalities of Araruna, Bom Sucesso, Candói, Castro, Colombo, Congoinhas, Mandaguari, Maringa, Rancho Alegre, and Rosario do Ivaí, which are situated in six mesoregions of Paraná (Western Center, East Center, South Center, Curitiba, North Central, and North Pioneer). These regions have $60 \%$ of the state herd (Secretaria de Estado da Agricultura e do Abastecimento [SEAB], 2017) and are located between latitudes $22^{\circ} \mathrm{S}$ and $26^{\circ} \mathrm{S}$.

The climate in these farms is subtropical and is classified according to Koppen (Instituto Agronômico do Paraná [IAPAR], 2017) as: Cfa, 
which cover most of the state, with hot summer and well-distributed rainfall throughout the year, and temperature over $22^{\circ} \mathrm{C}$; and $\mathrm{Cfb}$, with temperate summer and temperature does not exceed $22^{\circ} \mathrm{C}$.

The minimum number of serum samples $(\mathrm{n}=$ 270) to be tested was calculated using the EpiInfo $7{ }^{\circledR}$ program, considering that the average prevalence observed in 2014 was 30\% (95\% confidence interval and $6 \%$ standard error). The animals were randomly selected so that $10 \%$ of the total number of sheep were sampled from each farm.

The sampled animals belonged to Texel, Dorper, White Dorper, and Santa Inês races, were of both sexes and different ages, had no characteristic clinical signs of BT and could be naturally infected with BTV. Blood was collected in a vacuum test tube after local antisepsis and venipuncture of the jugular vein. It was stored without anticoagulant to obtain serum. The tubes were centrifuged and the sera were separated. The sera were then split into two $1.5 \mathrm{~mL}$ microtubes (duplicates), labelled, and frozen until further use.

For the detection of BTV antibodies, the sera were subjected to AGID (Bluetongue Virus Antibody Test Kit AGID-VMRD $\left.{ }^{\circledR}\right)$ and cELISA test kits. The AGID test was performed in the microbiology laboratory of the Veterinary Hospital of the Northern University of Paraná, campus of Arapongas - PR, using the manufacturer's protocol. The samples that formed the precipitation line were classified as positive. To validate the kit, a known positive blood serum sample was used; this sample was collected during the 2001 outbreak in Paraná (Clavijo et al., 2002) and was provided by the Paraná Agricultural Defense Agency, Curitiba. The other duplicate sample was sent to the Bovine Virus Laboratory of the São Paulo Biological Institute, where the cELISA test was performed using a commercial Bluetongue Virus Antibody Test Kit and following manufacturer's instructions. The samples that showed optical density values of $<50 \%$ of the mean optical density values of the negative control were considered positive. Two standard samples were used as controls (one positive and one negative).

To compare the results of the AGID and cELISA tests, a Kappa coefficient of agreement was calculated using the epiDisplay package of the $\mathrm{R}$ software (Chongsuvivatwong, 2018).

All procedures used in this study were approved by the Animal Use Ethics Committee of the Northern University of Paraná, Arapongas campus, under protocol 006/16.

\section{Results and Discussion}

According to the results it was decided to classify the farm as low occurence $(0-9.99 \%$ positive sheep), moderate occurrence $(10-49.99 \%$ positive sheep) and high occurence $(50-100 \%$ positive sheep). This was classified in this manner because there is no specification in the literature regarding the classification of sheep farms based on BTV infection in Brazil.

Of all the sheep tested, $64.81 \%(175 / 270)$ had antibodies against BTV as shown by the cELISA test, indicating high occurrence. On the contrary, $41.11 \%(111 / 270)$ were shown seroreactive by the AGID test, indicating moderate occurrence (Table 1). Of all the samples analyzed, $40 \%(108 / 270)$ of the sheep were seroreactive and $34.07 \%(92 / 270)$ were unreactive in both tests. Discordance was observed in only $1.11 \%(3 / 270)$ animals, which were positive only in the AGID test, and in $24.81 \%$ $(67 / 270)$ animals that were positive only in the cELISA test.

The number of animals found to be positive in the cELISA test was higher than those in the AGID test across all the farms that had seroreactive sheep. Further, the Kappa coefficient between the results of both tests showed a moderate agreement $(0.50)$ (Thrusfield, 2004). 
Table 1

Distribution of number and percentage of sheep detected seroreactive using the cELISA and AGID tests

\begin{tabular}{ccccc}
\hline \multirow{2}{*}{ County/ Farm } & Climate & No. of serum & \multicolumn{2}{c}{ Positive serum samples } \\
\cline { 4 - 5 } classification & samples analyzed & cELISA & AGID \\
\hline Araruna & $\mathrm{Cfa}$ & 30 & $20(66.67 \%)$ & $12(40.00 \%)$ \\
Bom Sucesso & $\mathrm{Cfa}$ & 26 & $24(92.30 \%)$ & $20(76.92 \%)$ \\
Candói & $\mathrm{Cfb}$ & 26 & $22(84.62 \%)$ & $16(61.53 \%)$ \\
Castro & $\mathrm{Cfb}$ & 40 & $4(10.00 \%)$ & $1(2.50 \%)$ \\
Colombo & $\mathrm{Cfb}$ & 27 & $0(0 \%)$ & $0(0 \%)$ \\
Cornélio Procópio & $\mathrm{Cfa}$ & 29 & $25(86.21 \%)$ & $12(41.38 \%)$ \\
Mandaguari & $\mathrm{Cfa}$ & 30 & $25(83.33 \%)$ & $19(63.33 \%)$ \\
Maringá & $\mathrm{Cfa}$ & 30 & $25(83.33 \%)$ & $11(36.67 \%)$ \\
Rancho Alegre & $\mathrm{Cfa}$ & 9 & $7(77.78 \%)$ & $2(22.22 \%)$ \\
Rosário do Ivaí & $\mathrm{Cfa}$ & 23 & $23(100 \%)$ & $18(78.26 \%)$ \\
\hline Total & - & $\mathbf{2 7 0}$ & $\mathbf{1 7 5 ( 6 4 . 8 1 \% )}$ & $\mathbf{1 1 1} \mathbf{( 4 1 . 1 1 \% )}$ \\
\hline
\end{tabular}

Probably, unlike the AGID test, the cELISA test was able to detect seroreactive sheep even when the antibody concentration was low. Several researchers have reported that the AGID test can be difficult to interpret because it is qualitative and not quantitative, has low sensitivity mainly in samples with low antibody titration, and may cross-react with other orbiviruses (Ward \& Thurmond, 1995; Chandel, Chauhan, \& Kher, 2003). In this study, only $1.11 \%(3 / 270)$ of the sheep were positive in AGID alone; this discrepancy between the two tests could be because of a cross reaction with other orbiviruses.

In this study, the cELISA test could detect $97.29 \%$ of sheep that were found seroreactive by AGID. Further, it detected 64 animals that were not positive in AGID, indicating to be more reliable. Similar results were observed by Shringi and Shringi (2005) when they observed that cELISA detected $100 \%$ of the sheep found to be seropositive by AGID and 37 more sheep that were not found to be positive by AGID. Although AGID has been recommended by OIE since 1982 because of its practicality and lower cost per sample, it is clear that it is not as sensitive as cELISA and is therefore being replaced by cELISA (Shringi \& Shiring, 2005).
In regions close to where the present study was conducted, in the Northern Central Mesoregion of Paraná, Negri et al. (2016) detected antibodies against BTV in dairy cattle using cELISA and the virus neutralization technique. They found $100 \%$ $(633 / 633)$ and $64.61 \%(409 / 633)$ positive samples, respectively, demonstrating the superiority of the cELISA test.

Corroborating the findings of the present study, Nogueira et al. (2009) compared the cELISA and AGID techniques in the state of São Paulo and found $74.3 \%(744 / 1002)$ of the sheep to be positive by cELISA and $65 \%(651 / 1002)$ by AGID, demonstrating a high occurrence of BTV antibodies in sheep $(50 \%-100 \%$ positive animals). Their observations also showed more sensitive antibody detection by the cELISA test and demonstrated the superiority of this test. Many dissertations have also reinforced the reliability of cELISA compared to AGID (Biihrer, 2017; Kawanami, 2017). In the state of São Paulo, Kawanami (2017) observed the occurrence of BTV antibodies in several ruminant species. They found that in sheep, $60.69 \%(105 / 173)$ and 55, 49\% (96/173) animals were positive, by cELISA and AGID, respectively. In Minas Gerais, Biihrer (2017) observed 56.44\% (171/303) positive sheep by cELISA and 54.13\% (164/303) by AGID. 
Similar results of high BTV occurrence were obtained in the states of Paraná, São Paulo, and Minas Gerais (Coetzee et al., 2012). This is because of the similarity between climates; all farms in these studies were distributed within the BTV occurrence zone of $50^{\circ} \mathrm{N}$ to $35^{\circ} \mathrm{S}$. The farms studied in this report were located between $22{ }^{\circ} \mathrm{S}$ and $26^{\circ} \mathrm{S}$, which also falls within the BTV occurrence zone. In addition, our results are consistent with those reported in the literature, which indicate high serum prevalence of BTV in subtropical regions, such as Paraná. Most of the territory in this region has hot summers and well distributed rainfall throughout the year; this condition combined with the absence of dry season favors the presence and multiplication of the Culicoid vector and the infection occurs throughout the year (Lobato et al., 2015).

The results obtained by serological tests showed that $90 \%$ of the farms $(9 / 10)$ presented at least one seropositive sheep, and only the farm located in the municipality of Colombo, metropolitan region of Curitiba, did not show BTV antibodies in any of the tests. These results demonstrate that, although clinical signs are not present, the virus is present in the sheep across most of the farms in Paraná, showing that the virus is spreading silently. Similar results were observed by Venditti (2009) in the state of São Paulo, where 85\% (11/13) of the farms presented at least one seroreactive sheep using both tests. Further, Nogueira et al. (2009) in São Paulo and Biihrer (2017) in Minas Gerais reported that $100 \%$ of the studied farms had BTV-seroreactive animals detected by both cELISA and AGID.

Overall, our results show that the regions classified as Cfa (hot summers, well distributed rainfall throughout the year, and average temperature above $22^{\circ} \mathrm{C}$ ) present higher occurrence of BTV than the regions classified as $\mathrm{Cfb}$ (mild summers with average temperature not exceeding $22{ }^{\circ} \mathrm{C}$ ) (Table 1). The farm located in Colombo, for example, has $\mathrm{Cfb}$ climate and has no BTV seroreactive sheep. A previous study has shown that as temperature decreases, BTV infection and transmission rates decrease (Mellor, 2000), which possibly explains the lower detection of antibodies in Colombo. Medlock and Leack (2015) have reported that BT and other Culicoid-transmitted diseases occur more or less frequently all over the globe, mainly because of climatic variations.

Despite the low occurrence of BTV observed in a farm located in a $\mathrm{Cfb}$ region, the first outbreak of the disease reported in Brazil in 2001 occurred in the same mesoregion (Metropolitana de Curitiba). At the time, Clavijo et al. (2002) isolated BTV serotype 12 from sheep and goats. Later, Negri et al. (2015) identified serotype 4 from clinically healthy cattle. Recently, serotypes 3, 14, 18, 19, and 22 (OIE, 2016) have been isolated after the death of bororo deer in an ecological reserve in Foz do Iguaçú, Paraná. This finding suggests that the presence of antibodies associated with the absence of clinical signs cannot exclusively justified by the climatic variations; low pathogenicity of circulating serotypes in different farms could also be a reason behind it.

\section{Conclusions}

Finally, it can be concluded that BTV infection is present in the sheep herds of Paraná. The occurrence was moderate as detected by the AGID test and high as detected by the cELISA test. Further study on the climatic variations and differences in serotypes present in different mesoregions is warranted to maintain disease surveillance and prevent further outbreaks.

\section{Acknowledgements}

We are grateful to the Coordination for the Improvement of Higher Education Personnel (CAPES) for their support in the research and to the Biological Institute of São Paulo for performing the cELISA tests. We thank the Paraná Agricultural Defense Agency (ADAPAR) of Curitiba for providing a seropositive sample that was used as a positive control. 


\section{References}

Alves, F. A. L., Alves, C. J., Azevedo, S. S., Silva, W. W., Silva, M. L. C. R., Lobato, Z. I. P., \& Clementino, I. J. (2009). Soroprevalência e fatores de risco para a língua azul em carneiros das mesorregiões do Sertão e da Borborema, semi-árido do Estado da Paraíba, Brasil. Ciência Animal, 39(2), 484-489. doi: 10.1590/S0103-84782008005000066

Batista, A. F. B., F'o., Oliveira, J. M. B., Silva, G. M., Oliveira, P. R. F., Borges, J. M., Brandespim, D. F., \& Pinheiro, J. W., Jr. (2018). Ocorrência e fatores de risco da infecção pelo vírus da língua azul em bovinos no Estado do Pernambuco. Pesquisa Veterinária Brasileira, 38(2), 250-255. doi: 10.1590/1678-5150PVB-4379

Biihrer, D. A. (2017). Inquérito sorológico da língua azul em ovinos de Minas Gerais. Dissertação de mestrado, Universidade Federal de Lavras, Lavras, MG, Brasil. Recuperado de http://repositorio.ufla.br/ jspui/handle/1/12745.

Chandel, B. S., Chauhan, H. C., \& Kher, H. N. (2003). Comparison of the standard AGID test and competitive ELISA for detecting bluetongue virus antibodies in camels in Gujarat, India. Tropical Animal Health and Production, 35(2), 99-104. doi: 10.1023/a:1022896117122

Chongsuvivatwong, V. (2018). EpiDisplay: epidemiological data display package ( $\mathrm{R}$ package version 3.5.0.1.). Retrieved from https://CRAN.Rproject.org/package=epiDisplay

Clavijo, A., Sepulveda, L., Riva, J., Pessoa-Silva, M., Tailor-Ruthes, A., \& Lopez, J. W. (2002). Isolation of bluetongue virus serotype 12 from na outbreak of the disease in South America. Veterinary Record, 151(10), 301-302. doi: 10.1136/vr.151.10.301

Coetzee, P., Stokstad, M., Venter, E. H., Myrmel, M., \& Van Vururen, M. (2012). Bluetongue: a historical and epidemiological perspective with the emphasis on South Africa. Virology Journal, 9(198), 1-9. doi: 10.1186/1743-422X-9-198

Costa, J. R. R., Lobato, Z. I. P., Herrmann, G. P., Leite, R. C., \& Haddad, J. P. A. (2006). Prevalência de anticorpos contra o vírus da língua azul em bovinos e ovinos do sudoeste e sudeste do Rio Grande do Sul. Arquivo Brasileiro de Medicina Veterinária e Zootecnia, 58(2), 273-275. doi: 10.1590/S010209352006000200017

Dorneles, E. M. S., Morcatti, F. C., Guimarães, A. S., Lobato, Z. I. P.; Lage, A. P., Gonçalves, V. S. P.,... Heinemann, M. B. (2012). Prevalence of bluetongue virus antibodies in sheep from Distrito Federal, Brazil. Semina: Ciências Agrárias, 33(4), 15211524. doi: 10.5433/1679-0359.2012v33n4p1521

Gang-Ma, J., Xuan Zhang, X., Bin Zheng, W., Tian Xu, Y., Quan Zhu, X., Xue Hu, G., \& Hui Zhou, D. (2017). Seroprevalence and Risk Factors of Bluetongue Virus Infection in Tibetan Sheep and Yaks in Tibetan Plateau, China. BioMed Research International, 2017(1), 1-5. doi: 10.1155/2017/5139703

Instituto Agronômico do Paraná (2017). Cartas climáticas do Paraná. Recuperado de http://www.iapar.br/ modules/conteudo/conteudo.php? conteudo $=863$

Jenckel, M., Bréad, E., Schulz, C., Sailleau, C., Viarouge, C., Hoffman, B.,... Zientara, S. (2015). Complete coding genome sequence of putative novel bluetongue virus serotype 27. Genome Announcements, 3(2), 1-2. doi: 10.1128/genomeA.00016-15

Kawanami, A. E. (2017). Virus da lingua azul em cevídeos neotropicais e bovídeos domésticos. Tese de doutorado, Universidade Estadual Paulista, Jaboticabal, SP, Brasil. Recuperado de http://hdl. handle.net/11449/147992

Lager, I. A. (2004). Bluetongue virus in South America: overview of viruses, vectors, surveillance and unique features. Veterinaria Italiana, 40(3), 89-93. Retrieved from http://www.izs.it/vet_italiana/2004/40_3/19. pdf

Lobato, Z. I. P., Guedes, M. I. M. C., \& Matos, A. C. D. (2015). Bluetongue and others orbiviruses in South America: gaps and challenges. Veterinaria Italiana, 51(4), 253-262. doi: 10.12834/VetIt.600.2892.1

Maclachlan, N. J. (2004). Bluetongue: pathogenesis and duration of viraemia. Veterinaria Italiana, 40(4), 462-467. Retrieved from http://www.izs.it/vet italiana/2004/40_4/462.pdf

Medlock, J. M., \& Leack, S. A. (2015). Effect of climate change on vector-borne disease in the UK. The Lancet Infectious Disease, 15(6), 721-730. doi: 10.1016/S1473-3099(15)70091-5

Mellor, P. S. (2000). Replication of arboviruses in insect vectors. Journal of Comparative Pathology, 123(4), 231-247. doi: 10.1053/jcpa.2000.0434

Morikawa, V. M., Pellizzaro, M., Paploski, I. A. D., Kikuti, M., Lara, M. C. C. S. H., Okuda, L. H.,... Barros, I. R., Fo . (2018). Serosurvey of bluetongue, caprine arthritis-encephalitis (CAE) and MaednaVisna in Barbary Sheep (Ammotragus lervia) of a Southern Brazilian zoo. Pesquisa Veterinária Brasileira, 38(6), 1203-1206. doi: 10.1590/16785150-PVB-4590 
Mota, I. O., Castro, R. S., Alencar, S. P., Lobato, Z. I. P., Lima, C. D. F., Fo ., Araújo Silva, T. L.,... Nascimento, S. A. (2011). Anticorpos contra o vírus do grupo da língua azul em caprinos e ovinos do sertão do Pernambuco e inferência sobre sua epidemiologia em regiões semiáridas. Arquivo Brasileiro de Medicina Veterinária e Zootecnica, 63(6), 1595-1598. doi: 10.1590/S0102-09352011000600045

Negri, L. C., Fo., Nogueira, A. H. C., Stefano, E., Katto, S., Okuda, L. H., Silva, L. C.,... Okano, W. (2016). Detecção de anticorpos contra o sorotipo 4 da língua azul (btv-4) em bovinos leiteiros da mesorregião norte central do Paraná, Brasil. Revista de Educação Continuada em Medicina Veterinária e Zootecnia do CRMV-SP, 14(2), 88. Recuperado de https:/www. revistamvez-crmvsp.com.br/index.php/recmvz/ article/view/32136

Nogueira, A. H. C., Pituco, E. M., Stefano, E., Curci, V. C. L. M., \& Cardoso, T. C. (2009). Detecção de anticorpos contra o vírus da língua azul em ovinos na região de Araçatuba, São Paulo, Brasil. Ciência Animal Brasileira, 10(4), 1271-1276. Recuperado de https://www.revistas.ufg.br/vet/article/view/3782

Pinheiro, R. R., Souza, T. S., Feitosa, A. L. V. L., Aragão, M. A. C., Lima, C. C. V., Costa, J. N.,... Brito, R. L. L. (2013). Frequência de anticorpos contra o vírus da língua azul em ovinos do estado do Ceará, Brasil. Arquivos do Instituto Biológico, 80(1), 35-42. doi: 10.1590/S1808-16572013000100006

Purse, B. V., Carpenter, S., Venter, G. J., Bellis, G., \& Mullens, B. A. (2015). Binomics of temperate ant tropical Culicoides midges: knowledge gaps and consequences for transmission of Culicoides-borne viruses. Annual Review of Entomology, 60(20), 373392. doi: 10.1146/annurev-ento-010814-020614

Roy, P. (2008). Functional mapping of bluetongue virus proteins and their interactions with host proteins during virus replication. Cell Biochemistry Biophysics, 50(1), 143-1578. doi: 10.1007/s12013008-9009-4

Sbizera, M. C. R., Cunha, L. F. C., Fo., Barreto, J. V. P., Locoman, D., Sudak, M. M., Finco, M. V., \& Souza, D. F. M. (2017). Ocorrência de anticorpos para o vírus da língua azul em ovinos da região Centro Sul do Paraná. Revista Acadêmica: Ciência Animal, 15(2), 41-42. doi: 10.7213/academica.15.S02.2017.20

Secretaria de Estado da Agricultura e do Abastecimento (2017). Dispõe sobre dados da pecuária paranaense. Governo do estado do Paraná. Departamento de Economia Rural. Recuperado de www.agricultura. gov.br

Shringi, S., \& Shringi, B. N. (2005). Comparative efficacy of standart AGID, CCIE, and competitive
ELISA, for detecting bluetongue virus antibodies in indigenous breeds of sheep and goats in Rajasthan, India. Journal of Veterinary Science, 6(1), 77-79. doi: $10.4142 /$ jvs.2005.6.1.77

Silva, T. G., Lima, M. S., Spedicato, M., Carmine, I., Teodori, L., Leone, A.,... Pituco, E. D. (2018). Prevalence and risk factors for bluetongue in the State of São Paulo, Brazil. Veterinary Medicine and Science, 4(1), 280-287. doi: 10.1002/vms3.113

Souza, T. S., Costa, J. N., Martinez, P. M., Costa, A. O., Neto, \& Pinheiro, R. R. (2010). Anticorpos contra o vírus da língua azul em rebanhos ovinos da microrregião de Juazeiro, Bahia. Arquivos do Instituto Biológico, 77(3), 419-427. Recuperado de http://www.biologico.sp.gov.br/uploads/docs/arq/ v77_3/ souza.pdf

Thrusfield, M. (2004). Epidemiologia veterinária (2a ed.). São Paulo: Roca.

Tomich, R. G. P., Nogueira, M. F., Lacerda, A. C. R., Campos, F. S., Tomas, W. M., Herrera, H. M.,... Barbosa-Stancioli, E. F. (2009). Sorologia para o vírus da língua azul em bovinos de corte, ovinos e veados campeiros no Pantanal sul-matogrossense. Arquivo Brasileiro de Medicina Veterinária e Zootecnia, 61(5), 1222-1226. doi: 10.1590/S010209352009000500028

Velic, L., Velic, R., Bajrovic, T., Dukic, B., \& Camo, D. (2004). Bluetongue in Bosnia: comparisons of competitive enzyme-linked immunosorbent assay and standard agar gel immunodiffusion tests. Veterinaria Italiana, 40(4), 562-563. Retrieved from http://www.izs.it/vet_italiana/2004/40_4/562.pdf

Venditti, L. L. R. (2009). Infecção pelo vírus da língua azul em ovinos e bovinos na região Sudeste do Brasil Dissertação de mestrado, Instituto Biológico, São Paulo, SP, Brasil. Recuperado de http://www. dominiopublico.gov.br/pesquisa/DetalheObraForm. do?select_action $=\&$ co_obra $=160378$

Ward, M. P., \& Thurmond, M. C. (1995). Climatic factors associated with risks of seroconversion of cattle to bluetongue viruses in Queensland. Preventive Veterinary Medicine, 24(2), 129-136. doi: 10.1016/0167-5877(94)00458-U

World Organization for Animal Health (2016). Report archive. Retrieved from http://www.oie.int/wahis_2/ public/wahid.php/Diseaseinformation/reportarchive

World Organization for Animal Health (2018). Bluetongue (Infection with bluetongue virus). In Manual of diagnostic tests and vaccines for terrestrial animals. Retrieved from https://www. oie.int/fileadmin/Home/ eng/Health_standards/ tahm/3.01.03_BLUETONGUE.pdf 